\title{
ANALYSIS OF BIOBEARINGS FRICTION AND WEAR PROCESSES
}

\author{
Michat Sobociński \\ Institute of Mechanical Technology, Czestochowa University of Technology \\ Częstochowa, Poland \\ sobocinski@iop.pcz.pl
}

\begin{abstract}
The paper draws up some issues connected with processes of friction and wear of bio-bearings. The non-Newtonian liquid lubrication in joints can be presented in tribological models. Considering a proper friction model allows us to mathematically stipulate the resistances that occur in natural joints. The paper includes empirical results of the analysis conducted to designate parameters of cooperation between the tissue and implanted materials. Friction resistances in modelled sets as well as curves of the wear have been assigned for the friction pairs.
\end{abstract}

Keywords: friction, wear, tribological model

\section{Introduction}

Liquid friction in bio-bearings makes the friction resistances relatively low. That kind of friction occurs in healthy joints when the surfaces of cartilages are totally separated by synovial fluid. That separation might by area be up to dozen micrometers [1]. The described case considers a mathematical model of the biobearing.

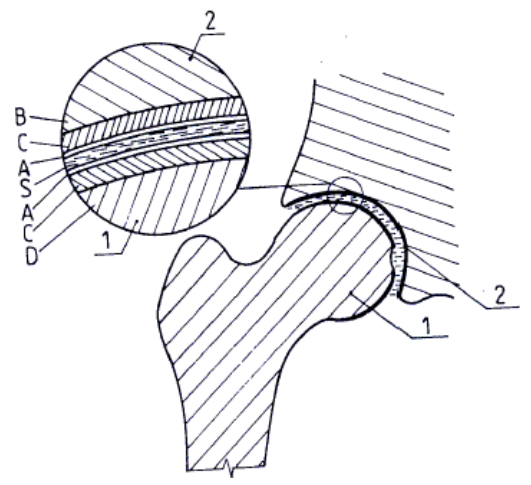

Fig. 1. Technical drawing of hip joint. S - liquid, A - layer on cartilage, B - pelvis bone, $\mathrm{C}$ - cartilage, D - hip bone, 1 - head, 2 - pelvis [2] 
Friction force $F_{r}$ and friction coefficient $\mu$ can be shown:

$$
\begin{gathered}
F_{R}=\frac{\eta \cdot V \cdot A}{h} \\
\mu=\frac{F_{R}}{P}
\end{gathered}
$$

where:

$\eta$ - dynamic viscosity of synovial fluid $\left[\mathrm{Ns} / \mathrm{m}^{2}\right]$,

$V$ - average speed of shear thickening of synovial fluid $[\mathrm{m} / \mathrm{s}]$,

$A$ - surfaces of bone tissues in contact $\left[\mathrm{m}^{2}\right]$,

$h$ - average width or thickness of synovial fluid layer [m],

$P$ - joint load $[\mathrm{N}]$.

The friction is mostly influenced by dynamic viscosity of synovial fluid.

In order to define bearing capacity and friction of the bio-bearing, it is important to assign pressure distribution in liquid lubrication in the joint. That distribution is described by Reynolds equation in curvilinear coordinate system [3]:

$$
\begin{gathered}
\alpha_{i}, i=1,2,3 \\
\frac{1}{h_{1}} \frac{\partial}{\partial \alpha_{1}}\left(\frac{h^{3}}{\eta} \frac{\partial p}{\partial \alpha_{1}}\right)+\frac{1}{h_{3}} \frac{\partial}{\partial \alpha_{3}}\left(\frac{h_{1} h^{3}}{h_{3} \eta} \frac{\partial p}{\partial \alpha_{3}}\right)=6 \omega h_{1} \frac{\partial h}{\partial \alpha_{1}}
\end{gathered}
$$

If the synovial fluid is extruded, the right side of the equation is:

$$
\frac{1}{h_{1}} \frac{\partial}{\partial \alpha_{1}}\left(\frac{h^{3}}{\eta} \frac{\partial p}{\partial \alpha_{1}}\right)+\frac{1}{h_{3}} \frac{\partial}{\partial \alpha_{3}}\left(\frac{h_{1} h^{3}}{h_{3} \eta} \frac{\partial p}{\partial \alpha_{3}}\right)=12 V h_{1}
$$

where:

$p$ - pressure,

$V$ - velocity of cooperating bones,

$\alpha_{1}, \alpha_{2}, \alpha_{3}$ - coordinates of curvilinear system,

$h_{1}, h_{3}$ - Lamé's coefficients.

Values of Lamé's coefficients:

- for thin coating of spherical surface

$$
\alpha_{1}=\phi, \alpha_{2}=r, \alpha_{3}=\Theta
$$

become:

$$
h_{\phi}=R_{0} \sin \phi, h_{r}=1, h_{\theta}=1
$$

where $R_{0}$ is the spherical radius of the joint head,

- for the cylindrical surface of the joint, where:

$$
\alpha_{1}=\phi, \alpha_{2}=r, \alpha_{3}=\mathrm{z}
$$


become:

$$
h_{\phi}=R_{0}, h_{r}=1, h_{z}=1
$$

- for a thin layer of parabolic surface:

$$
h_{\alpha_{1}}=\operatorname{acos}^{2}\left(\alpha_{3} A\right), h_{\alpha_{2}}=1, h_{\alpha_{3}}=\sqrt{1+4 a^{2} A^{2} \sin ^{2}\left(\alpha_{3} A\right) \cos \left(\alpha_{3} A\right)}
$$

where:

$$
\begin{aligned}
& A=\frac{1}{b} \sqrt{\frac{a-a_{1}}{a}} \\
& a, a_{1}-\text { maximum and minimum bone radius, } \\
& b \quad \text { - half of the bone height. }
\end{aligned}
$$

With liquid friction, the bearing force and friction of the bio-bearing are shown by formulas [3]:

$$
\begin{gathered}
P=\frac{\pi R_{0}^{2} \eta^{2}}{\rho \varepsilon^{2}} \\
F_{R}\left(\alpha_{3}\right)=F_{0} \int_{0}^{2 \pi}\left(\int_{b_{m}}^{b_{s}} \eta\left(\alpha_{3}\right) \frac{\partial V_{\alpha_{1}}}{\partial \alpha_{2}} d \alpha_{3}\right) d \alpha_{1}
\end{gathered}
$$

where:

$R_{0}$ - bone head radius [m],

$\eta$ - dynamic viscosity of synovial fluid $\left[\mathrm{Ns} / \mathrm{m}^{2}\right]$,

$\rho$ - density of synovial fluid $\left[\mathrm{N} / \mathrm{m}^{3}\right]$,

$\varepsilon \quad$ - height, thickness of the synovial fluid layer [m],

$V_{\alpha_{1}}$ - component tangential velocity of synovial fluid in direction $\alpha_{1}$.

Movable joints are highly resistant to wear and have a low friction coefficient value. Considering that joint, it is worth paying attention to the simplified lubrication model, where the structure of the synovial liquid changes when the friction surfaces are subjected to an external force stimulant. That model is defined by a three differential equation system of the first order; the right sides of the equations depend on time [4].

$$
\left\{\begin{array}{c}
\dot{\rho}=b_{s}+c \cdot \rho-\delta \rho^{2} \\
\dot{\phi}=e_{s}+N_{H A} \cdot k \cdot[1-\phi] \\
\dot{k}=C_{K} k\left[\kappa-\kappa^{-1}\right]
\end{array}\right.
$$

There are two contrary figures in the equation: $c \cdot \rho$ - a factor defining surface defects, and $\delta \rho^{2}$ stands for those defects decay. The defects decay replaces a water molecule with SAPL (surface active phospholipid) molecule which effects in the system of two SAPL molecules and one water molecule. That process is called surface hydrofobization [5]. 
Coefficients in equations are equal due to reversibility and symmetry of the dynamic process:

$a=e$ - independent parameters responsible for external sources, define the number free SAPL, in one time unit,

$b=f$ - define coupling of one effect against the other, assign the surface and its interactions with SAPL,

$b_{S}, e_{S}$ - linear functions, respectively $\phi$ and $\rho$,

$C_{K} \quad$ - resistance to tribopolymerization,

$k \quad$ - friction coefficient $\mu, \mu=k^{-1}$,

$\kappa \quad$ - ionic channel.

\section{Defining parameters of the friction process in the samples}

It is quite common to apply so-called half-life endoprostheses in alloplasty, which consist of a polyethylene or metal head and an anatomic cup. Most popular of hip joint endoprostheses's friction pairs are: metal head (CoCrMo alloy) - anatomic cup (synovial cartilage); or UHMWPE head and anatomic cup. That combination is adverse due to the cartilage compliance to tribological wear and further complications connected $[6,7]$.

All the wear debris increases the resistance and intensify the wear processes $[8,9]$.

Friction and wear tests of the samples conducted on simulator T-05 make it possible to assign the wear curves, define friction coefficient and on the T-05 simulator check variation of temperature in the friction node during testing.

Test parameters:

- unit pressure $4.5 \mathrm{~N} / \mathrm{mm}^{2}, 6 \mathrm{~N} / \mathrm{mm}^{2}$,

- friction surface $100 \mathrm{~mm}^{2}$,

- rotation speed 0.91 rot./s,

- lubricating medium: distilled water.

The sample (half-cup) has been made of beef bone tissues, the contra-sample of the alloy CoCrMo. The scheme of that friction node is presented in Figure 2.

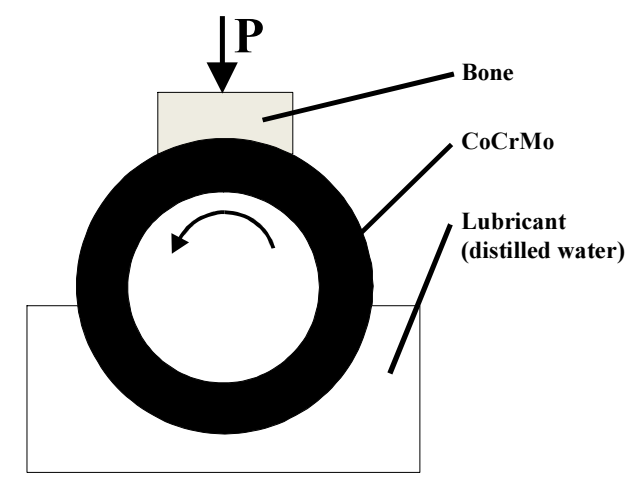

Fig. 2. Friction node used for tests 
Wear curves of the sample and contra-sample are presented in Figures 3 and 4.

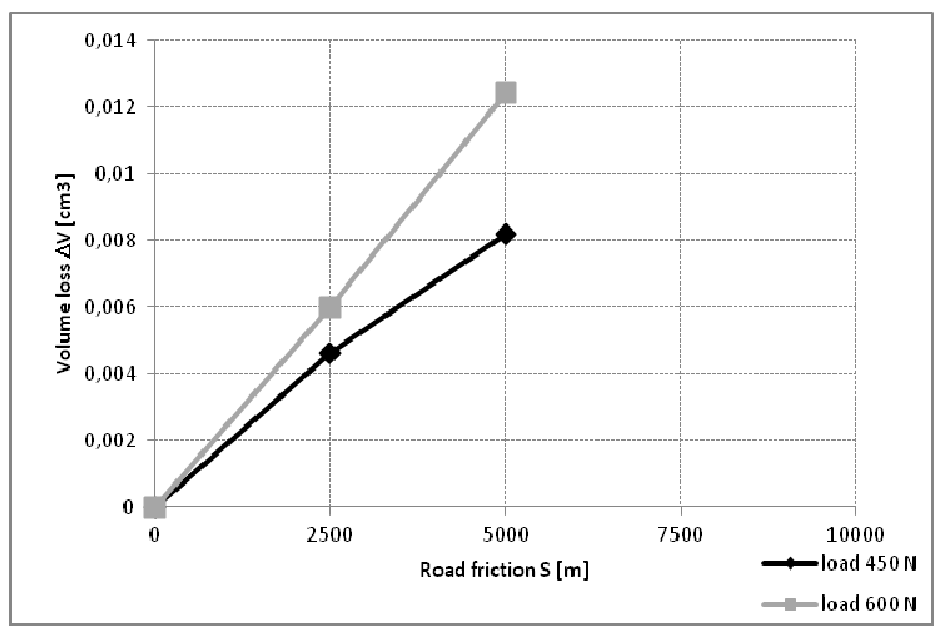

Fig. 3. Wear variation of the sample (half-cup) made of bone tissue, on friction path at different loads

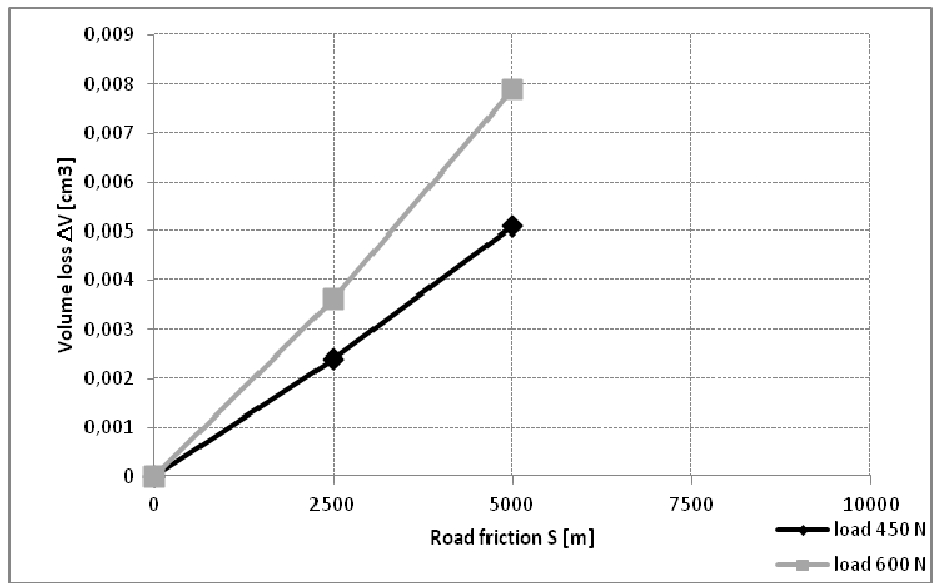

Fig. 4. Wear variation of the contra-sample made of CoCrMo alloy, on friction path at different loads

The tests were conducted with an attempt to continue on the distance of $10,000 \mathrm{~m}$, but after friction on ca. $5,000 \mathrm{~m}$, the tests were terminated due to high destruction of the half-cup made of bone tissue. There were observed several cracks, orthogonal to the contact surface with the contra-sample, which caused fragmentation of the bone tissue. The graphs prove that both the sample and the contra-sample have been highly worn within a short friction path. There were observed several pieces of debris in the friction node, occurring in the lubrication fluid as well as deep wear crack on the surface of the contra-sample (ring), in the area where it contacted the sample. 
Cooperation of that friction pair affected in high friction resistance. Figure 5 presents the friction coefficient variation for the node subjected to loads: 450 and $600 \mathrm{~N}$ respectively, on the friction path.

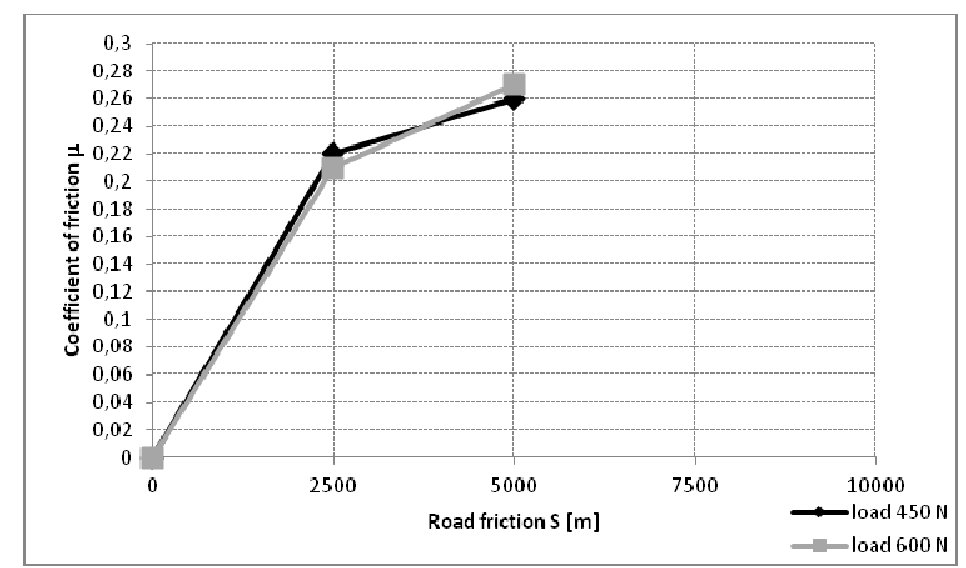

Fig. 5. The variation of the friction coefficient for the pair bone tissue - CoCrMo, lubricated with distilled water, on the friction path at different loads

The tested friction pair showed features of a high friction coefficient reaching at the end of the test $\mu=0.26$ for both loads. It must be pointed out that the temperature of the friction node during the test ranged between $41 \div 45^{\circ} \mathrm{C}$, at constant lubrication of the node with distilled water.

\section{Conclusions}

1. The friction pair bone/CoCrMo presented the same or a similar friction coefficient $\mu=0.21 \div 0.27$ at different loads: 450 and $600 \mathrm{~N}$.

2. The sample made of bone tissue was quickly destructed when cooperating with contra-sample made of CoCrMo alloy and lots of wear debris occurred both from the sample and contra-sample. That destruction caused loss of stability and terminated the tests.

3. The sample made of bone tissue was much more fragile and less resistant to destruction than the contra-sample made of CoCrMo alloy.

\section{References}

[1] Wierzcholski K., Czajkowski A.A., Rodzaje tarcia w biotribologii, Materiały II Sympozjum Inżynieria Ortopedyczna i Protetyczna IOS'99, Białystok 1999, 357-369.

[2] Wierzcholski K., Pytko S., The parameters calculation method for biobearing lubricated with non-Newtonian lubricants, Tribologia 1993, 1/93(127), 9-12. 
[3] Gierzyńska-Dolna M., Biotribologia, Wydawnictwo Politechniki Częstochowskiej, Częstochowa 2002.

[4] Bełdowski P., Gadomski A., Modelowanie dysfunkcji chrząstki stawowej - propozycja fizykochemicznych i mechanicznych miar jej zużycia, Uniwersytet Technologiczno-Przyrodniczy w Bydgoszczy, http://imif.utp.edu.pl/zmpf/images/AG_pliki/Publikacje

[5] Pawlak Z., Gadomski A., Biotribologiczne i molekularno-agregacyjne aspekty tarcia i smarowania $\mathrm{w}$ chrzastkach stawowych: model $\mathrm{w}$ konfrontacji $\mathrm{z}$ eksperymentem i zastosowaniem praktycznym, http://www.oic.lublin.pl/cudzechwalicie/3-3d.html

[6] Popko J., Dąbrowski J.R., Badania tribologiczne stawu biodrowego po założeniu endoprotezy połowicznej w obserwacjach eksperymentalnych, Chirurgia Narządów Ruchu i Ortopedia Polska 1996, LXI, Supl. 3A, 127-131.

[7] Stachowiak G., Batchelor A., Friction and wear changes in synovial joints, Wear 1994, 171, 135-142.

[8] Sobociński M., Nabrdalik M., Analiza produktów zużycia elementów polietylenowych endoprotez stawów biodrowego i kolanowego, [in:] Polimery i kompozyty konstrukcyjne, ed. G. Wróbel, Gliwice 2008, 143-152.

[9] Sobociński M., Procesy zużycia w elementach polietylenowych endoprotez stawu biodrowego, Czasopismo Techniczne. Mechanika 2006, 6, 103, 445-448. 